\title{
"Diz que em corumbá tem muita conversa fiada": fofoca, política e moralidade em uma cidade do Pantanal
}

Gustavo Villela Lima da Costa'

\section{Resumo}

A cidade de Corumbá-MS possui pouco mais de cem mil habitantes e a fofoca é um fato social reconhecido pelos seus moradores em seus efeitos e alcance. Baseado na leitura de Bailey (1971), o estudo busca pensar nas relações que se estabelecem entre a fofoca e a política em torno das reputações pessoais e no pertencimento a uma ou mais "comunidades morais" na cidade, aqui nomeada de circuitos sociais da fofoca. Além disso, o estudo da fofoca pode contribuir etnograficamente para investigações sobre vários elementos da estrutura social da cidade: as relações de trabalho, os modos de se fazer negócios na fronteira, sobre a política local e a formação das hierarquias sociais, sobre a chegada de migrantes, sobre os significados de relacionamentos amorosos, relações de gênero, sobre a construção dos papéis sociais e do status e o posicionamento social dos indivíduos no "mapa" da cidade.

Palauras-chave: Fofoca. Política. Moralidade.

A cidade de Corumbá, fundada em 1778, às margens do rio Paraguai, está situada na fronteira com a Bolívia a partir do município vizinho de

I Professor Adjunto do Departamento de Ciências Humanas da Faculdade de Formação de Professores, da UERJ, São Gonçalo-RJ. Docente do Programa de Pós-Graduação em História Social (PPGHS). Email: gustavovillelalimadacosta@gmail.com Commons. Com essa licença você pode compartilhar, adaptar, para qualquer fim, desde que atribua a autoria da obra, forneça um link para a licença, $e$ indicar se foram feitas alterações. 
Puerto Quijarro, possui em torno de 100 mil habitantes (IBGE, 2010) e tem no comércio uma de suas principais atividades econômicas, junto da pecuária e da mineração. Nessa fronteira há uma conurbação de quatro cidades que, juntas, têm em torno de 160 mil habitantes: Corumbá e Ladário, no lado brasileiro, e Puerto Quijarro e Puerto Suarez, no lado boliviano. Outra característica importante da região é a sua distância de grandes centros urbanos como Santa Cruz de la Sierra, na Bolívia (aproximadamente $600 \mathrm{~km}$ ) e Campo Grande $(450 \mathrm{~km})$. Miranda (MS), a cidade seguinte depois da fronteira, fica a cerca de $200 \mathrm{~km}$ de Corumbá, e entre as duas cidades estão as terras alagáveis do Pantanal.

Entre 2009 e 2014 fui professor da Universidade Federal de Mato Grosso do Sul (UFMS) no Campus do Pantanal, em Corumbá. Nesse período, atuei como docente no Mestrado em Estudos Fronteiriços, onde desenvolvi pesquisas sobre a identidade fronteiriça, sobre o comércio informal realizado por bolivianos e seus descendentes na cidade e sobre a economia ilegal na regiáo. Embora a fronteira nacional tenha sido o tema principal dessas pesquisas, havia um fenômeno social onipresente na cidade, e que sempre me chamou a atenção como antropólogo: a fofoca.

Para produzir este artigo, então, utilizo-me de uma dimensão subjetiva importante do trabalho etnográfico, que é a vivência de quase cinco anos na cidade, que me permitiu ser afetado pessoalmente pelos eventos etnográficos que estudava, em que fui obrigado a manejar as fofocas e estabelecer algum controle, proteção e construção sobre minha reputação. $\mathrm{Na}$ verdade, o próprio trabalho etnográfico envolve a participação do antropólogo nas fofocas, sejam aquelas que são feitas sobre ele, seja no momento em que vai participando da vida social e sendo aceito e compreendido por seus interlocutores, que passam a fofocar com ele assuntos da cidade, do grupo e do universo social pesquisado. Besnier (2009) destaca que a fofoca é central para entender o que os antropólogos fazem no trabalho de campo, pois tanto parte dos dados que os antropólogos conseguem são fruto de fofocas, quanto são parte de uma essência da disciplina, que é o interesse no trivial e mundano. Assim, parte considerável das análises deste artigo são resultado de minha vivência na cidade de Corumbá e de minha participação ativa e intensa na vida social da cidade, como alvo de fofocas e propagador de fofocas também, como todo mundo. 
Além dessa vivência e observação participante na cidade, comecei, desde 2010, a fazer entrevistas e anotações de situaçôes em que a fofoca aparecia como um fenômeno de grande importância para as pessoas, seja para os negócios, para a vida amorosa, profissional, seja para investigaçóes policiais, e até mesmo para a política local. Ao longo desse percurso, fiz em torno de 30 entrevistas com moradores e ex-moradores de Corumbá. Em 2015, já morando no Rio de Janeiro, decidi organizar esse material e senti falta de algumas informaçóes à medida que os temas centrais da fofoca foram aparecendo na pesquisa. Assim, realizei ainda mais dez entrevistas pelo Facebook e por Whatsapp, com conhecidos, ex-alunos, colegas e amigos. As redes sociais também foram uma importante fonte de pesquisa, em páginas de relacionamento, de política e de festas da cidade de Corumbá.

Essa pesquisa se iniciou a partir de alguns grupos sociais em que havia mais proximidade e intimidade entre as pessoas (a fofoca sempre começa com quem está perto). Os locais de trabalho foram o primeiro foco de investigação, a partir de empresas privadas e instituiçóes públicas como a UFMS, a Embrapa, as Forças Armadas, e a Vale (mineradora), principalmente. Nessas entrevistas, surgiu a primeira questão a ser trabalhada no artigo: a diferença entre as pessoas "de fora" e os corumbaenses e moradores mais antigos. Um segundo foco de fofoca que surgiu nas entrevistas foi a vizinhança, que afeta principalmente moradores mais antigos. Como eu pretendo integrar essas dimensóes, tanto do trabalho quanto doméstica, na cidade como um todo, procuro pensar nesses locais de pesquisa como "circuitos sociais da fofoca", isto é, espaços sociais nos quais circulam as fofocas e as pessoas e onde essas pessoas são mais afetadas por esses falatórios. Identifico, no artigo, também uma diferença importante, já que a vizinhança tende a afetar mais os corumbaenses ou moradores mais antigos que já têm laços sociais mais estabelecidos e implicaçóes sociais maiores em ser vizinho, pois muitas pessoas de fora, mesmo que sejam "faladas" pelos vizinhos, ainda não ligam ou não são tão afetadas por esses comentários. De outro lado, os locais de trabalho tendem a afetar mais as pessoas de fora e estabelecem, muitas vezes, conflitos com os corumbaenses ou moradores mais antigos, nos quais estão em jogo disputas por posiçóes sociais e profissionais, reputaçóes e prestígio social. 
Gluckman (1963) talvez tenha sido o primeiro antropólogo a pensar nas implicaçóes morais da fofoca e em sua importância como um dos "principais fenômenos societais e culturais", que pode contribuir para a união de grupos contra grupos rivais e para a coesão social a partir do controle exercido sobre indivíduos que rompam com os valores morais grupais. Elias e Scotson (2000) contribuem para esta pesquisa ao afirmarem que um grupo com maior integração tende a fofocar mais livremente que um grupo menos integrado e que as fofocas, no primeiro caso, tendem a reforçar uma coesão já existente. Paine (1967) levou adiante essa questão fazendo consideraçóes sobre moralidade e competiçôes pelo status moral, mas não necessariamente sobre a unidade do grupo, levando as análises sobre fofoca para um plano instrumental. Isso porque, para esse autor, dados importantes sobre a "ordem moral" de um grupo podem ser conseguidos etnograficamente ao observarmos as manipulaçóes e manejos feitos por indivíduos de acordo com seus interesses.

Entretanto, como se poderá ver ao longo do artigo, é impossível separar totalmente esses circuitos sociais de fofoca que em diversos momentos se interpenetram e se ampliam, pois as pessoas circulam entre eles, sobretudo aqueles que passam mais tempo na cidade, tornando-se cada vez mais imbricados nessa teia de falatórios e reputaçóes. As redes sociais na Internet têm também um papel fundamental na difusão de fofocas e na interligação desses circuitos de fofoca, assim como em sua velocidade de propagação. Por fim, na última seção do artigo, procuro analisar, baseado no que me disseram as pessoas, quais são os assuntos mais falados na cidade: as relaçóes amorosas e as questóes de dinheiro, o que me leva a pensar nas questóes de gênero e na criminalidade, como desdobramentos desses temas.

\section{Corumbá, terra da fofoca}

Uma cena típica da cidade Corumbá-MS, situada na vasta planície pantaneira, são pessoas reunidas no fim de tarde ou nos fins de semana, tomando tereré ${ }^{2}$, sob a sombra frondosa de uma árvore sete copas (amendoeira), protegendo-se do calor abrasante e jogando conversa fora,

\footnotetext{
Bebida composta por água gelada e erva mate, tomada socialmente (em geral com cuia ou copo) e uma
} bomba, semelhante ao chimarrão (que é com água quente). 
proseando com amigos e vizinhos. Sobre o que conversam as pessoas? Sobre o que conversamos, afinal? Sobre política, futebol, novelas, economia, sobre o calor, "ala'! tá quente, guri!", e qualquer assunto que mantenha a conversa de pé, como em qualquer lugar do mundo. Mas, é claro, como todas as pessoas de qualquer lugar do mundo, em Corumbá também se fofoca, a vida alheia é um dos assuntos preferidos nas rodas de tereré, nos corredores do trabalho, nos bares e até mesmo nas redes sociais.

Um termo nativo que se usa para fofoca na cidade de Corumbá é "conversa fiada". Quando se usa esse termo, ele não significa apenas jogar conversa fora, mas tem um sentido valorativo, algo como uma possível mentira, ou boato, ou uma fofoca, cuja veracidade não se pode comprovar. Nem toda conversa, porém, é fofoca. Tomemos a definição do Dicionário Houaiss da Língua Portuguesa: "Dito maldoso; mexerico; disse-me-disse. Afirmação não baseada em fatos concretos; especulação. Aquilo que é comentado sobre outrem". Reparamos que essa definição de fofoca incorpora três elementos principais que precisamos reter para entender o sentido da fofoca ao longo do artigo: em primeiro lugar, é preciso que haja alguma "maldade", ou "veneno", no que é dito, o que impóe uma intencionalidade do ator social; em segundo lugar, há sempre uma dúvida, sobre o que se diz, ou seja, não há como comprovar se, de fato, é totalmente verdade o que se propaga nas fofocas, o que gera um fator constante de tensão e disputa; e, por fim, é preciso que se fale sobre a vida alheia, sobre o "outro", que não está presente na conversa, numa interação "pelas costas". Isto promove a circulação e abrangência da fofoca, pois todo mundo é um "outro", que não está presente em alguma conversa. Como vemos nas entrevistas abaixo, há toda uma interpretação "nativa" sobre o fenômeno da fofoca em Corumbá, como parte da cultura da cidade, de sua estrutura e até mesmo como um "mecanismo de sobrevivência" social. Além disso, aparece a ideia de algo que aprisiona e cria um controle social bastante intenso na cidade.

“Eu me sinto preso aqui. Em três prisões. Uma geográfica, porque Corumbá é longe de tudo. Uma climática, porque é muito quente durante quase o ano inteiro. E uma social. E essa é a pior das três. É muita fofoca, todo mundo cuidando da sua vida". (Y. homem, 43 anos, mora em Corumbá há 5 anos).

3 "Ala": expressão de surpresa, espanto. 
"O nome desta cidade deveria ser mudado: terra da fofoca. Aqui é incrivel o prazer de cuidar da vida alheia. E digo prazer não à toa. Parece que a pessoa chega a ter orgasmos quando vai falar mal ou fofocar.Tem uma tia minha que fala que ela sente prazer em fofocar. Ela mesma diz pra não contar nada pra ela, se não quiser que se espalhe. Ela diz que não consegue guardar segredo e que sente uma angústia e ansiedade enorme quando tenta". ( $A$. Mulher, 28 anos, moradora, nascida em Corumbá).

"Corumbá é conhecida como a capital do Pantanal, poderia ser conhecida como a capital dos falatórios, por ser uma cidade pequena, em que todos os habitantes praticamente se conhecem, nem que seja por memória fotográfica, como diz o "povo". (F. homem, 32 anos, morador, nascido em Corumbá).

"Em Corumbá a fofoca já está naturalizada, faz parte da cultura. O argumento é: "Corumbá é uma cidade pequena, todo mundo sabe de tudo". As pessoas costumam sentar na calçada de suas casas e ficam observando tranquilamente a vida alheia, sem o menor pudor. Alguns até "torcem o pescoço" quando alguém passa, tudo isso na intenção de ver melhor, de ter certeza. Algumas familias até observam em conjunto, "torcem os pescoços" ao mesmo tempo. É hilário! É da cultura, totalmente naturalizado, banalizado, esperado. As pessoas chegam a se reunir exatamente com o propósito de fofocar. Penso que é uma espécie de catarse, onde as pessoas literalmente "colocam pra fora" tudo que não têm coragem de fazer ou de falar, doa a quem doer. Parece até que se aliviam com a fofoca". (T. Mulher, 40 anos, mora em Corumbá há 4 anos).

"Fofoca na minha opinião chega a ser um modo de sobrevivência das pessoas daqui, (...) ela é toda uma cultura desse lugar, dessa cidade". (U.28 anos, homem, morador, nascido em Corumbá).

"Faz parte da estrutura social. Corumbá não seria Corumbá sem fofoca, está entranhado em todas as esferas sociais da cidade e em todos os negócios". (I. Homem, 38 anos, morador, nascido em Corumbá).

A fofoca é compreendida pelas pessoas como um fenômeno onipresente em Corumbá, afetando a vida das pessoas e seus relacionamentos sociais. As fofocas entram no circuito das relaçóes de troca e, como afirma Bailey (1971, p. 2), “[...] nenhuma dádiva está totalmente descontaminada do veneno das relaçôes humanas”. Embora raramente alguém se assuma fofoqueiro, as fofocas movem a vida social e são propagadas e devoradas com grande júbilo e prazer. Como Comerford observou na zona da mata mineira, a "[...] fofoca é algo que todos dizem que há, mas ninguém diz 
que faz" (COMERFORD, 2014, p. 9). Elias e Scotson (2000) notam que as fofocas têm alto valor de entretenimento e fornecem o tempero da vida social, a partir de suas doses de "veneno", pois, para esses autores, as notícias sobre o desrespeito das normas aceitas, principalmente cometidos por pessoas conhecidas são muito mais saborosas e interessantes de serem contadas, e isso vale tanto para Winston Parva, quanto para Corumbá, certamente, como se observa nas entrevistas apresentadas. Nessas falas foi recorrente o uso de expressóes ou sentidos que evocavam a sensaçáo de "sufocamento", ou de "envenenamento" da vida social na cidade, tanto para pessoas nascidas e criadas em Corumbá, quanto para as pessoas que vieram de fora.

Quando cheguei em Corumbá, em 2009, aprovado no concurso para professor adjunto da UFMS, fui alertado inúmeras vezes por pessoas da cidade para ter cuidado pois "o povo aqui é muito fofoqueiro". Uma pessoa chegou a me dizer: "olha, se você estiver pensando em fazer alguma coisa que te dê vontade, faça! Porque se você não fizer o povo inventa do mesmo jeito!'. Também escutei mais de uma vez que "aqui em Corumbá, toda mulher solteira é biscate, todo rico é traficante e todo homem casado é corno". A expressão normalmente utilizada quando se começa uma fofoca em Corumbá é o "diz que". "Diz que" fulano está traindo a mulher com sicrana, "diz que" beltrano é traficante, e assim por diante. Essa expressão, que tem um sujeito indeterminado, incorpora uma das ambiguidades da fofoca, marcadas por Paine (1967), pois parece que ela é feita por um coletivo abstrato e não por pessoas concretas. Como ressalta o autor, quem faz fofoca não é a comunidade, mas as pessoas: "É o indivíduo que fofoca e não a comunidade." (1967, p. 280). O "diz que" nos leva diretamente a essa questão, pois parece que o sujeito indeterminado é a cidade, como se a fofoca estivesse no ar, ocultando que foram pessoas específicas que iniciaram sua propagação. Quem diz o quê? Sobre quem? O que se pode dizer? E sobre quem se pode falar? depois de a fofoca ser difundida, é como se não fosse ninguém especificamente que tenha dito aquilo; a fofoca se torna então aparentemente impessoal, ou seja, todo mundo sabe e todo mundo pode propagar a informaçáo: "diz que" fulano fez tal coisa, mas dificilmente se pode "rastrear" quem foi o indivíduo que "lançou" a fofoca na rua, por onde ela começou. Esse é o caráter trágico da fofoca, pois ninguém sabe 
de onde ela veio, ninguém diz, mas todos sabem. Em cidades pequenas há um nível de "envenenamento" da vida social, com implicaçôes políticas, sociais e psicológicas, contra as quais as pessoas adquirem mecanismos de proteção e de navegação social. Há sempre presente nas fofocas um grau de sofrimento e de medo social, em função do devassamento da vida privada e da possibilidade de ruína das reputaçóes.

"O ambiente fica tóxico. Bem, a saúde mental das pessoas é afetada diretamente pelas fofocas. Cada pessoa reage de uma maneira, algumas caem em depressão profunda e vão embora, outras ficam agressivas e bélicas, outros andam pelas sombras, na tentativa de não serem notados, mas, no fundo, o seu sofrimento está igual ou maior do que os outros. As vidas das pessoas são literalmente acompanhadas, como se fossem novelas. Os fofoqueiros e fofoqueiras de plantão não têm limites, não têm ética". (T. mulher, 40 anos, mora há 4 anos em Corumbá).

"Acredito que a maiorias das pessoas já passaram por isto, eu não sou exceção, já fui vitima, porém prefiro ficar na minha sem tirar satisfações, pois todas as vezes que fui vítima, a verdade venceu as tendências de fofoca. As causas dessas conversas sem fundamentos me deixaram bastante nervosa, porque foi algo que afetou minha familia e relacionamento, mas preferi deixar de lado. Conheço muitas pessoas que já sofreram com estas fofocas, tem uma que chegou até a delegacia, em virtude da gravidade das conversas, acusações e apontamentos. É triste, porque muitas pessoas sofrem transtornos psicológicos e corporais em virtude destas fofocas, se rebaixam com medo de enfrentar as situações". (G. Mulher, 22 anos, moradora, nascida em Corumbá).

A fofoca possui esse caráter "mágico" de homologação ao ser proferida, um poder objetivador de criar o fato dito (BOURDIEU, 1989) e se tornar uma verdade, que circula na boca do povo, contra a qual o indivíduo que foi objeto da fofoca mal pode se defender. Está feito. A eficácia da fofoca reside em sua propagação de pessoa a pessoa. Resta a quem for atingido em sua reputação e honra aguardar para que outro assunto de maior importância ou de maior veneno circule e tome o lugar da fofoca, que fica "antiga" e é parcialmente esquecida. Assim se constroem e destroem reputações e se marcam as pessoas associadas a determinados eventos ou comportamentos na cidade.

A fofoca faz parte do aprendizado social na cidade e é amplamente reconhecida como um fenômeno local de alta intensidade, como um "fato social”, que pode afetar a vida das pessoas. É preciso saber se proteger das 
maledicências e é preciso saber fofocar, saber com quem fazê-lo, e em qual momento apropriado. Então, para Abrahams, a fofoca pode ser pensada, “[...] não apenas como sistema de valores ou técnica para adquirir poder, mas como um 'sistema de performance..", a partir do qual o pesquisador pode observar as regras de etiqueta e decoro, assim como os procedimentos pelos quais "[...] se estabelecem os acordos de permissão para um indivíduo 'fazer sua performance'."(ABRAHAMS, 1970, p. 300).

Para esse autor (1970), a fofoca ocorre entre pessoas que têm uma relação "especial" entre si. Esse relacionamento mais íntimo, observado a partir das fofocas,é o que permite também que as pessoas façam piadas e gracejos umas com as outras, revelando aspectos da "estrutura formal e informal de uma comunidade ou grupo". A fofoca segue algumas formas convencionais de ação, ou seja, ela é uma performance específica, que por ser pública, incorpora alguma dramatização dos valores sociais do grupo. Em Corumbá notamos essas relações entre fofoca, performance, habitus e corpo. $\mathrm{Na}$ arte de fofocar em público - em bares, igrejas, no trabalho e assim por diante - se estabelece toda uma técnica corporal e vocal, que envolve o cochicho, a mão na frente, o falar baixo, o olhar para o lado constante, a troca de olhares caso alguém se aproxime, a desconfiança, o uso de "apelidos" internos para se referir a determinada pessoas etc.

A cidade de Corumbá também tem uma grande tradição festeira, com grandes eventos populares na rua, como o Carnaval, com dezenas de blocos e desfile de escolas de samba e o São João, com o tradicional "banho do santo", no rio Paraguai. Uma tradição recente, ainda, é construída em torno do Festival América do Sul, que teve sua 12a edição em 2015. Todos esses são eventos de participação maciça da população, em que "ver e ser visto" impóe performances específicas na observação dos comportamentos alheios, na difusão de mensagens sobre o que se vê e se escuta. Esses circuitos são amplificados por sites como "www.corumbaladas.com.br" e "www. vitrinevirtual.com", que fazem a cobertura desses eventos e publicam fotos das pessoas comuns, moradores da cidade, em festas (em bares, boates e restaurantes também). A Internet funciona como uma coluna social da cidade de ampla visualização, na qual qualquer pessoa comum vira "celebridade" por alguns instantes, produzindo novas modalidades de performances (com os dispositivos eletrônicos, aplicativos, fotos e vídeos) e muita 
"falação", obviamente Além disso, as redes "virtuais" amplificam o alcance da fofoca, sua velocidade de disseminação, transcendendo a necessidade das interaçóes face-a-face.

"Para não ser alvo destas pessoas fofoqueiras evito expor minha vida pessoal, principalmente nas redes sociais que hoje tem sido uma grande ferramenta para desvendar a vida alheia. As pessoas adoram fofocar dos videos que compartilham nos grupos de whatsapp etc. Já as mulheres têm muito mais assunto, os mais comuns são: beleza, roupas, casa, vizinha, whatsapp, facebook. Muitas perdem horas buscando informações nas redes sociais para fofocar e ter assunto novo quando encontrar as "amigas"." (G. Mulher, 22 anos, moradora, nascida em Corumbá).

Todos em Corumbá têm um nome, um rosto, um cargo, uma reputação. Além disso, as pessoas podem ser colegas de trabalho, mas ao mesmo tempo são vizinhas de alguém que é parente de um colega do trabalho, ou são casadas com parentes ou comadres de algum vizinho ou colega de trabalho, formando uma rede intrincada de circuitos sociais de fofoca na cidade. Para cada um há uma série de comportamentos e expectativas, que escapam ao controle de cada indivíduo. Para Bailey (1971), pertencer a uma comunidade não depende de o indivíduo ter uma boa reputaçáo, basta ter uma reputação para fazer parte dela. Corumbá possui ainda um importante contingente de pessoas "de fora”, em função de trabalhos vinculados ao Estado brasileiro (como as forças armadas, receita federal, órgãos de segurança e vigilância, a UFMS e a Embrapa), além da mineração (Vale) e do comércio, que atrai uma população de pessoas de outras cidades e estados do Brasil.

\section{As pessoas "de fora": disputas e conflitos}

O caso dos estrangeiros, ou forasteiros, (sobretudo dos recém-chegados) também é destacado por Bailey (1971), que afirma que as fofocas em geral não os atingem num primeiro momento, pois ainda não fazem parte da "comunidade moral", que implica não apenas certo grau de compartilhamento de valores e comportamentos, mas em algum nível de competição e disputa entre as pessoas. Os forasteiros, caso não fiquem na cidade, são absolutamente desinteressantes para os fofoqueiros e não se fofoca sobre eles. No momento em que a pessoa se insere em relaçóes de trabalho, 
afetivas, amorosas e estabelece trocas simbólicas cada vez mais intensas, começam a circular informaçóes sobre sua vida pessoal, borrando as esferas do público e do privado, ao mesmo tempo em que ela começa a receber informaçóes das pessoas com as quais convive. A fofoca gira primeiro no circuito íntimo. Conforme nos aponta Bailey (1971), o primeiro rival ou competidor - o primeiro inimigo, em suma - é, em geral, o mais próximo no nível social (rank). O mais próximo é aquele com que interagimos mais e por isso também gera mais causas de conflito: a competição, de fato, ocorre entre "iguais". É com os vizinhos, colegas de trabalho e pessoas próximas com as quais se iniciam os jogos de poder, a competição, as rivalidades e alianças. E é sobre eles que fofocamos mais. Para os corumbaenses, nascidos e criados na cidade, as fofocas de vizinhos incomodam muito mais do que aos forasteiros, que têm de lidar, prioritariamente, com as fofocas do ambiente de trabalho. Demora algum tempo para que alguém se "torne vizinho" socialmente, a ponto de se incomodar com as fofocas e ter de participar mais ativamente da política de vizinhança. Ser um vizinho não é apenas morar numa casa próxima no bairro, é preciso estar imerso nas relaçôes sociais para se tornar um "vizinho". Um caso típico de briga entre vizinhos foi relatado em uma entrevista e é paradigmático de que esse nível de intimidade, tensão e conflito só pode se dar com quem tem um convívio muito próximo, de anos, o que jamais aconteceria com uma pessoa "de fora". São outros dramas sociais que estão em jogo nas fofocas entre vizinhos.

"Aconteceu com uma de minhas irmãs. Ela e sua vizinha eram tão amigas a vizinha todos os dias não deixava de ir na casa dela, conversa vai e conversa vem, e um belo dia a minha irmã ficou sabendo por uma outra pessoa que essa vizinha andou fofocando, difamando no bairro fatos sobre a sua pessoa tipo: aquela mulher é uma vagabunda, caloteira, quer tomar o meu marido. Ela chamou a tal vizinha e a pessoa que falou pra ela pra ver se solucionava a situação constrangedora. A pessoa que foi contar pra minha irmã confirmou tudo o que a vizinha tinha dito a respeito de minha irmã, a vizinha se transformou e disse exaltada: "eu falei mesmo você é uma vagabunda mesmo, que tá de olho no meu marido, caloteira mascateio vive batendo aqui no seu portão e você nunca paga", pra que!, começou o bate-boca, minha irmã respondeu mais exaltada ainda: "se eu devo não é da sua conta, vagabunda é você que se diz que tem marido mas vive andando com "fulano de tal" e eu não estou inventando, isso foi você quem me falou... e outra... eu não estou de olho no seu marido, ele é quem fica dando em cima de mim várias vezes ele me convidou pra sair com ele! Eu é que não quero, porque tenho respeito a você e seus filhos. Achei que você era 
minha amiga, agora eu vi que vocês dois são uns safados se merecem, mas isso não vai ficar assim não, some daqui da minha casa!". Naquele mesmo dia minha irmã foi fazer um boletim de ocorrência por calúnia e difamação contra a sua vizinha, e foram parar no fórum." (W. Mulher, 42 anos, moradora, nascida em Corumbá).

A presença das pessoas "de fora" é muito importante para a vida social de Corumbá, que é uma cidade historicamente formada por imigrantes e que têm até hoje grande fluxo de pessoas, por ser um local estratégico para o Estado e para as pessoas que utilizam a fronteira como um recurso econômico e simbólico. Há na cidade um "localismo", uma identidade regionalista e um orgulho grande em ser "corumbaense". A importância histórica e cultural da cidade são objeto de narrativas entre os moradores, assim como o fato de a cidade ser considerada como a "capital do pantanal". Ao mesmo tempo, porém, há um discurso recorrente do "já foi” e do "já teve”. A cidade "já foi” mais importante, "já teve” dois cinemas, a pecuária e a elite "já foram" mais poderosas, a cidade "já foi” mais relevante e cosmopolita que Campo Grande, Dourados e Três Lagoas e assim por diante. Há toda uma narrativa da decadência, de uma cidade que teria perdido sua importância de outrora, sua riqueza, seu patrimônio. Colado a esse discurso, há outro de grande importância e que remete diretamente às pessoas "de fora". O de que a riqueza "passa por Corumbá, mas náo fica”. Esses discursos se repetem na cidade: o gasoduto passa por Corumbá, mas não tem gás na cidade; a Vale extrai o minério e a riqueza não fica, as pessoas fazem negócio na fronteira $\mathrm{e}$ o dinheiro vai embora e o mais importante para os propósitos desse artigo: as pessoas trabalham em Corumbá por um tempo, fazem dinheiro e carreira e vão embora, "não deixando nada para trás".

Assim, as pessoas "de fora", os forasteiros são sempre objeto de desconfiança - muitas vezes vistos como ameaça ao poder local estabelecido - e de falação: "vai ser mais um que vai embora, né? vai usar Corumbá pra subir na vida”. Isso vale para militares, professores universitários, funcionários da Vale e outros postos de trabalho. Uma funcionária do Banco do Brasil relatou: "quem tem conta em banco aqui é o povão, só pobre mesmo. Os altos funcionários da Vale não abrem nem conta na cidade. Ficam um tempo e vão embora". Ou então, como afirmou outro morador, "esse professor nem mora na cidade, mora em Campo Grande?". Há sempre nesses discursos a ameaça constante de que Corumbá estaria sendo vista como uma espécie 
de "degredo" por parte das pessoas "de fora", que usariam o período em que ficam na cidade para ter ganhos financeiros ou de carreira. No funcionalismo público, presenciei um debate interessante na UFMS, a respeito do "adicional de penosidade", que pode proporcionar um aumento salarial de $30 \%$, aos funcionários federais que fossem morar nas fronteiras ${ }^{4}$. Esse benefício foi cortado durante os anos de 1990, e havia técnicos administrativos e professores da UFMS que reivindicavam sua volta. Outros professores e técnicos, nascidos em Corumbá, demonstraram seu descontentamento com a ideia de um benefício de "penosidade", que implica em seu nome a ideia de "atividade penosa" ou "pena" a ser cumprida na cidade e manifestaram essa repulsa em assembleia, tornando público esse conflito. É quase como se a reputação da cidade, que se torna quase um sujeito em questão, estivesse em jogo e ela mesma fosse objeto de fofoca. É nesse contexto, em uma dinâmica social similar a descrita por Elias e Scotson (2000) em "estabelecidos e outsiders", que o forasteiro, a pessoa "de fora" vai se tornando membro da cidade de Corumbá: ao mesmo tempo em que vai ouvindo (e propagando) fofocas e informaçóes pessoais das demais pessoas, vai construindo sua reputação, que é construída pelos outros e por ele próprio por meio de seu comportamento, de suas escolhas. Em alguma medida, somos sujeitos da construção de nossas reputaçôes.

Nesse momento o outsider vai conhecendo quais são as reputaçóes das pessoas com quem convive (pela sua própria observação e pela fala dos outros, pelas fofocas): primeiro no círculo próximo e depois em outros circuitos sociais. Além disso, é comum escutar de recém-chegados reclamaçóes contra a intensidade e volume de fofocas sobre eles que são imediatamente produzidas e que começam a circular. Sáo novidade na praça, objetos de

4 Há um debate no estado de Mato Grosso do Sul a respeito do pagamento de adicional a partir da Lei 12.855/2013, sob a denominação de indenização, aos servidores públicos federais situados em localidades estratégicas, vinculadas à prevenção, controle, fiscalização e repressão de delitos transfronteiriços. Especificamente, são descritos os funcionários lotados nas delegacias e postos do Polícia Federal e da Polícia Rodoviária Federal e os servidores que trabalham em unidades da Receita Federal e dos ministérios da Agricultura e do Trabalho. Além disso, a Lei 8.1/2, de 1990, o Estatuto dos Servidores Públicos Federais, o qual dispõe sobre o regime jurídico dos servidores públicos civis da União, também tratou do adicional de penosidade, e há a reivindicação de que esse adicional de atividade penosa seja aplicado aos servidores em exercício em zonas de fronteira, ou em localidades cujas condições de vida o justifique, nos termos e condições limites fixados em regulamento. Para mais detalhes ver: http://www.conjur.com.br/2015-set-08/servidor-federal-atua-fronteira-receber-adicional 
grande interesse para os fofoqueiros: é preciso criar uma reputação, uma marca para os recém-chegados, como um batismo de entrada na cidade.

Comerford (2014) entende que há nessas conversas e fofocas elementos para observarmos certo "mapeamento social" e os posicionamentos de indivíduos e grupos na sociedade. Essas ideias nos permitem apreender que a própria "localidade" moral, em grande medida, é construída oralmente em Corumbá.

Essa grande produção de conversas que quase sempre embutem falar dos outros e falar de si (abrangendo um "nós") é fundamental para situar uns em relação aos outros, suas proximidades e distâncias, identidades e alteridades relativas, e constituí-los como coletividade (relativamente) ordenada (e sempre relativamente desordenada, ou em reordenamento). É como se fosse um processo de mapeamento, em que não é exatamente um mapa que se produz, pois cada um estabelece seu posicionamento a partir de perspectivas distintas entre si, e essa perspectiva se desloca a cada nova conversa (cada nova conversa desloca um pouco - ou nem tão pouco - o conjunto das coordenadas interpretativas de todas as outras conversas). (COMERFORD, 20I4, p. 10).

Por esse motivo a situaçáo do forasteiro é peculiar, pois ainda não é parte desse "mapa" social, não está situado em nenhum ponto dessa rede de posicionamentos, não participa ainda de disputas e interaçóes, ou seja os outros ainda não competem com ele. Para Besnier (2009), não é que os outsiders estejam excluídos da fofoca, mas que essa exclusão da fofoca é um dos primeiros significados através do qual o grupo define o status de outsider. O próprio Gluckman (1963) afirma em seu artigo que se sentia excluído do grupo que pesquisava na África, por náo saber de fofocas suficientes, para escutá-las ou para contá-las e que nunca aprendeu totalmente as normas grupais sobre como e em que momento fazer as fofocas "adequadas". Em geral o outsider, o forasteiro não participa das fofocas, já que a fofoca é a "marca do pertencimento" social e é um marcador social das fronteiras de determinado grupo (GLUCKMAN, 1963).

\section{Fofoca e (micro)política}

Há sempre muita informação circulante sobre cada pessoa em Corumbá (informação que pode ficar restrita a um pequeno circuito, ou dependendo da importância social do indivíduo, chegar na "boca do povo"). 
Bailey (1971) aponta que os indivíduos têm, em grande medida, que saber manejar as regras do jogo social, navegando pelo espaço social, tanto para preservar sua identidade e autointeresse, quanto para se adequar ou servir aos interesses da "comunidade" ou grupo. A todo momento estão em jogo avaliaçóes sobre as condutas, em torno do egoísmo e altruísmo, e há possibilidades abertas de ação política na luta pela igualdade ou pela manutenção de hierarquias ou desigualdades. Concordamos com Paine (1967), que entende que o fofoqueiro procura controlar, em alguma medida o fluxo de informaçóes, a audiência ou alvo a que se dirige, no sentido de aumentar seu status social, mais do que buscar um controle grupal de valores socialmente compartilhados. O fofoqueiro em geral "[...] deseja receber mais do que dá. Tem grandes orelhas e parte de sua arte reside no arranjo de um fluxo constante de informação para si." (PAINE, 1967, p. 283). É assim que o fofoqueiro procura controlar esse fluxo de informaçáo de acordo com seus interesses, já que há sempre alguma informação que ele deseja que as pessoas saibam, fazendo com que sua versão prevaleça e não a de outros. Além disso, para esse autor, o fofoqueiro distribui a informação como uma série de prestaçóes, em uma complexa rede de trocas de informação e de poder (PAINE, 1967).

"Outro ponto importante está no fato de a fofoca se tornar uma estratégia para conseguir algum objetivo a custa de outra pessoa. É a fofoca como "aviso" (I. homem, 38 anos, morador, nascido em Corumbá).

"Diante dessa lógica, aprendi a me beneficiar da fofoca. Sei quem são os principais fofoqueiros, aqueles que, se você contar, pronto, a fofoca espalha na velocidade da luz, vou lá e finjo que não quero que seja contado pra ninguém. É certeiro, espalha na hora. Pedindo em segredo então, mais rápido a fofoca espalha. (risos). Tem que rir pra não chorar!" (T. Mulher, 40 anos, mora em Corumbá há 4 anos).

Há aqueles que procuram se defender das fofocas que possam envolvê-los e há diferentes estratégias para proteção de sua reputação e controle das informaçóes. Algumas entrevistas apontam estratégias de proteção de busca por romper o ciclo de propagaçáo da fofoca e buscar diretamente o encontro com os envolvidos. Há quem diga também, que nenhuma estratégia é possível, que a fofoca será inevitável: 
"Aprendi que fofoca se corta pela raiz. Se alguém me conta alguma, não continuo contando a fofoca. Assim ela não se espalha. Caso eu queira saber o que realmente aconteceu, e se isso me envolve, pergunto pras pessoas envolvidas os fatos e tento resolver." (J. mulher, 23 anos, nascida em Corumbá, mora em Campo Grande).

"Protejo-me sempre. Sim, porque a fofoca deixa qualquer ambiente em desequilibrio. A meIhor maneira em que acredito é tornar-se "antissocial", ou seja, me fechar ao máximo com as pessoas que não são meus amigos, dificultando o acesso a minha vida pessoal, dando confiança aqueles que são realmente importantes." (F. homem, 32 anos, morador, nascido em Corumbá).

Outro exemplo de estratégia de proteção das reputaçóes e das fofocas ocorre com jovens casais da cidade. Pude observar, durante os quatro anos em que morei em Corumbá, que era muito comum que assim que se formavam os casais de universitários, muitos deles meus alunos, imediatamente desapareciam da vida noturna e social da cidade, seja porque poderiam encontrar ex-namoradas ou namorados, seja porque seriam alvo do falatório das demais pessoas, reproduzindo a estratégia de J. citada anteriormente de tornarem-se "antisociais". Um aluno me confidenciou: "aqui um casal não pode ser feliz. A inveja estraga. Inventam um monte de coisas pra envenenar.. falavam que eu traí minha namorada... ela brigou comigo. Epra provar que era mentira?"

A partir da leitura de Bailey (1971) podemos pensar nas relaçóes que se estabelecem entre a fofoca e a micropolítica (small politics) em torno das reputaçóes pessoais, baseadas em relações de troca, que têm sua contrapartida de "veneno". Para esse autor, por trás dessa micropolítica existe tanto um conjunto de ideias e valores compartilhados "sobre como a vida e as pessoas são e devem ser", quanto um código para comunicar essas ideias e valores; ou seja, essa micropolítica tem grande importância na vida social, pois concerne tanto ao poder, à geração e resolução de conflitos e disputas, quanto à solidariedade, coesão e alianças como variáveis na interação. Besnier (2009) aponta a necessidade de pesquisar a emergência da prática política no cotidiano, onde a hierarquia e igualitarismo coexistem e onde as fronteiras do público e do privado são muito tênues.

As disputas políticas em Corumbá também podem ser lidas como disputas por prestígio, como afirma Paine (1967), em que diminuir o prestígio 
do outro pode aumentar o seu próprio, ou seja, seu prestígio depende da incapacidade dos seus rivais ou inimigos de te denegrirem. Um entrevistada relatou que os políticos locais utilizam as redes sociais (Facebook e WhatsApp) para lançarem fofocas, boatos e ataques pessoais às reputaçóes dos rivais. A vida pessoal dos políticos em cidades "pequenas" é bastante devassada, sobretudo em detalhes íntimos que caem na "boca do povo", papel que cabe à grande imprensa nas metrópoles e que, mesmo assim, não chegam ao grau de intimidade possível nas cidades menores. Recentemente dois corumbaenses "famosos" na cidade, o senador Delcídio do Amaral e o pecuarista José Carlos Bumlai (investigados e presos na operação "Lava Jato"), estiveram nas páginas políticas e policiais do Brasil, o que fomentou muita falação na cidade de Corumbá, sobretudo na elite local, intimamente relacionada aos dois por laços de parentesco, amizade e negócios. A política local passa também por esses canais da fofoca, seja no boca a boca, seja nas redes sociais, em que as reputaçôes ficam sempre no "fio da navalha”. Os políticos locais são parentes, vizinhos, amigos, compadres ou comadres de alguém e, portanto, fazem parte de alguns desses circuitos sociais de fofoca, não ficando imunes às falações. Muitas das críticas políticas se disseminam como uma forma de comunicaçáo que fica indistinta entre a crítica político-social e a fofoca, que cai no boca a boca e nas redes sociais. A fofoca pode ser considerada como uma modalidade de troca de informaçóes. Essas performances têm resultados efetivos nas eleiçóes e na opinião pública (como é o caso do grupo fechado no Facebook, "Desabafa Corumbá", que faz oposição ao prefeito), em que a população fala de problemas da cidade, fazendo denúncias online. Assim, os políticos também dispóem dessas estratégias de contra fofocas, por parte de grupos aliados, a fim de manter equilibradas suas reputaçôes na cidade. Observei nas páginas do Facebook discussóes pessoais entre políticos e políticas com moradores da cidade, quase numa modalidade de bate bocas entre vizinhos. Obviamente no caso da política "institucional”, há uma série de interesses em jogo, como rivalidades políticas, processos eleitorais, implantaçáo de políticas públicas e interesses públicos e privados que afetam o teor, intensidade e o momento das fofocas sobre a vida privada dos políticos locais. As fofocas podem ser fofocas propriamente "políticas" sobre uso de dinheiro público, obras e gestão, por exemplo, mas podem ter um teor pessoal, até mesmo sobre vida sexual ou práticas ilícitas entre outros assuntos. 
"Há também outra peculiaridade aqui. As fofocas nas redes sociais de cunho político! tipo opositores infernizando os outros! falam sobre tudo! obras, reputação, tudo! "(L. Mulher, 38 anos, moradora, nascida em Corumbá).

"Fofoca pra Corumbá é o que nos leva a um caminho ruim, principalmente na área da política, palauras distorcidas acabam atrapalhando políticos bons que realmente se importam em melhorias para a cidade. Calúnias, difamações e em ano eleitoral surgem muitas fofocas. Na maioria das vezes os homens fofocam a respeito de um fato ocorrido no meio político, pois, não procuram saber, ler, se informar da realidade do fato ocorrido e acabam inventando pra ganhar prestígio em meio a uma roda de amigos um quer falar mais que 0 outro." (Q. Mulher, 24 anos, moradora, nascida em Corumbá).

"A pessoa mais visada é o próprio prefeito. Falam não só sobre a vida pessoal dele, mas principalmente sobre a gestão... A última fofoca que vi foi antes do carnaval, sobre os casos de hInI. Aqui a cidade está dividida: entre os que são a favor da atual gestão; os que são contra; e os que não podem dizer que é contra, pois perde o cargo na prefeitura." (Y. Mulher, 54 anos, moradora, nascida em Corumbá).

É justamente essa micropolítica (small politics), que se constrói nesse espaço entre as pessoas que nos interessa estudar, a fim de entendermos suas relaçóes com o que se convencionou chamar de "política", em sentido mais amplo. Não se trata, entretanto, de duas esferas distintas da política. As relações pessoais de reciprocidade e a política "institucional” estão interconectadas, já que a "política de reputaçôes" está distribuída por toda a sociedade 5 (BAILEY, 1971). Compreender essas relaçóes políticas mais isonômicas, que se apresentam etnograficamente sob o fenômeno da fofoca, nos permite ir além do preconceito moderno a respeito do que se convencionou chamar de política, associada à soberania, ao Estado ou a um governo central. Nesse sentido concordamos com a crítica feita por Arendt (2006), a respeito dessa visão reducionista da política como atividade humana, associada apenas ao uso da violência de Estado, como no caso dos fenômenos totalitários, ou restrita plano da administração e dominação burocráticas.

5 Agradeço à leitura e aos comentários feitos por Luciana Schleder Almeida, Professora Adjunta da UNIVERSIDADE DA INTEGRAÇÃO INTERNACIONAL DA LUSOFONIA AFRO-BRASILEIRA, especialmente sobre a "política de reputações" estudada por ela em sua tese a respeito dos agricultores de soja de Mato Grosso e a relação entre moralidade comunitária e o acesso a crédito financeiro (ALMEIDA, 2013). 
A vida política é certamente um fenômeno muito mais abrangente da vida social, e essa política vinda "de baixo", tem sido um dos objetos preferidos da antropologia e dos trabalhos etnográficos como Malinowski (1976) e Evans-Pritchard (1978), demonstraram. Para Besnier (2009), como a fofoca é difícil de reprimir e controlar, ela permite dar voz a pessoas ou grupos excluídos do palco político e, assim, pode se tornar tanto uma ferramenta de resistência e protesto mas também de opressão (de gênero, étnica e contra alguns outsiders principalmente, como vemos no caso de Corumbá). Mas no momento, vamos reter esse sentido de isonomia, que a fofoca possui e que nas palavras de Arendt,

"[...] não significa que todos são iguais perante a lei nem que a lei seja igual para todos, mas sim que todos têm o mesmo direito à atividade política; e essa atividade na polis era de preferência uma atividade da conversa mútua. Por isso, isonomia é, antes de mais nada, liberdade de falar." (ARENDT, 2006, p. 18).

Como se dá essa dinâmica da vida política em Corumbá? Quais os efeitos práticos dessa "liberdade de falar"? Quais as relaçóes de poder e conflitos que se desvelam ao estudarmos as fofocas na cidade? A fofoca, por um lado, "iguala" um pouco as pessoas no sentido de que todos podem falar sobre todos, já que não é possível controlar sua produção e propagação. Por outro lado, como vimos até aqui, a fofoca também hierarquiza as pessoas e os comportamentos, porque todos falam a partir de posiçóes hierarquizadas e em disputa entre si. Para Gluckman (1963), quanto mais exclusivo é um grupo, maior a quantidade de fofoca que aí existe. Um dos exemplos que o autor nos dá desse tipo de grupo são as categorias profissionais, que conformam uns dos principais circuitos de Corumbá (e em qualquer parte). Assim, em Corumbá, a fofoca circula pela cidade, pois há uma comunicação entre esses circuitos - sobretudo pelas pessoas que estão em suas interseçôes - e que podem fazer a fofoca alcançar a "opinião pública geral”. A fofoca tem grande importância na ação política, nas disputas por poder, na construção e destruição de reputaçóes, na manipulação de verdades, assim como na formação de alianças e conflitos entre pessoas e posiçóes sociais.

"O que já observei aqui na cidade e que é muito forte, são as fofocas entre esposas de militares que se fecham em alguns grupos para falar das vestimentas, vida financeira, cabelo, 
casa, redes sociais e festas badaladas que acontecem no circulo de vivencia delas e da cidade. Outro tipo de fofoca é no ambiente de trabalho, acontecem muitos problemas de convivência em virtude de fofocas que rodeiam este local, parece que as pessoas fofoqueiras sentem prazer em ver o constrangimento do outro. E outra fofoca muito forte é entre vizinhas, esta é bem comum e acontecem várias discussões e até briga dependendo do assunto." (G. Mulher, 22 anos, moradora, nascida em Corumbá).

Assim, a propagação de fofocas na cidade depende das alianças, das relaçóes de obrigação e do prestígio social dos envolvidos. Não apenas a política "institucional" é alvo das fofocas como vimos até aqui. As disputas na cidade também são resolvidas nas arenas públicas das fofocas. Um caso citado em entrevista abaixo ilustra bem esse processo. As disputas por posiçôes no trabalho e por emprego podem ter gerado a demissão de um funcionário devido a uma fofoca. Por esse motivo, a fofoca só pode ser compreendida se colocada em contextos mais amplos de relaçóes sociais e dinâmicas simbólicas, como um veículo por meio do qual os agentes fazem as coisas acontecerem ou náo (BESNIER, 2009). Outro caso abaixo apresenta uma situação de perseguição moral em torno da orientação sexual de um funcionário de uma instituição de ensino na cidade (que será omitido, por motivos óbvios). Os efeitos sociais das fofocas dependem de disputas sociais por prestígio e por isso é preciso observar quem fala, pra quem fala e qual é o tema em disputa.

"Dentro do ambiente de trabalho uma pessoa a qual conhecia foi grande vítima, vários falatórios levaram a sua demissão, certamente por motivos merecidos e impulsionados por fofoca. A vítima descumpriu as normas da empresa, mas não tinha sido descoberta, gerou-se grande fofoca a respeito do acontecimento, implicando no seu desligamento como funcionário." (F. homem, 32 anos, nascido em Corumbá).

"Sei de pessoas em Corumbá que foram vítimas de fofoca. Falavam muito de sua orientação sexual, com quem a pessoa se relacionava. A pessoa teve uma depressão e pediu transferência para outra cidade." (J. Mulher, 23 anos, nascida em Corumbá, mora em Campo Grande).

Relembramos ainda que, em muitos casos, a fofoca não trata apenas de um juízo moral sobre uma conduta que não seja "correta" ou "normal", ou de um modelo moral dominante, mas principalmente o fofoqueiro busca atingir um fim, que pode ser a demissão de um rival, a remoção de uma pessoa da cidade, ou a separação de um casal, por exemplo, utilizando, 
para esse fim, uma "gramática" dos valores morais vigentes, para atingir a reputação pessoal. Assim, para alcançar um fim prático, a fofoca é utilizada como uma tática ou estratégia, que se utiliza dos padróes normalizadores e morais vigentes para atingir determinadas pessoas ou grupos. Nem todos os atores sociais que participam da propagação da fofoca têm consciência desse fim prático e racional, que atende a determinados interesses individuais que alguns atores sociais procuram manipular. Mas a fofoca se propaga porque há algum compartilhamento dos modelos ideais de determinado grupo ou sociedade, e que servem como padróes de julgamento das condutas.

É preciso lembrar que o fofoqueiro pode sempre ser "criminalizado" moralmente por propagar algo sobre alguém. "Foi fulano que falou isso de você", "escutei ele dizer", e assim por diante. Há, portanto, sempre um risco calculado em propagar uma fofoca para uma pessoa errada, ou aliada de algum envolvido no caso fofocado. Esse risco em fofocar implica num jogo social sempre imprevisível: como os atores sociais podem controlar o fluxo da fofoca? até onde ela chega? quem atinge? quais seus efeitos sociais e sua eficácia? Em vez de pensar a fofoca apenas do ponto de vista da coesão ou conflito, Paine nos alerta que a fofoca é um "catalisador de processos sociais", ou seja, um "[...] instrumento social poderoso para qualquer pessoa que aprenda manejá-la” (PAINE, 1967, p. 283).

Quanto mais enraizada e mais antiga for um pessoa de Corumbá, mais informaçóes de diferentes circuitos de fofoca ela possui. Assim, alguns habitantes de Corumbá que passam a vida na cidade, por um lado detêm mais informação, o que lhes permite controlar seu fluxo e utilizá-la melhor conforme seus interesses; por outro, estão mais enredados em formas de controle social, em relaçóes de troca e reciprocidade (positiva e negativa), que impedem alguns movimentos e açóes no jogo social. Para compreendermos a circulação de informação por esses circuitos sociais da fofoca em Corumbá, levamos em conta o argumento de Paine (1967) de que as pessoas têm necessidade de obter informaçóes de fora de seus grupos e circuitos sociais (entre gêneros, classes, famílias, bairros etc). 


\section{Sobre o que se fofoca?}

Ao longo das pesquisas realizadas chegamos a dois assuntos principais sobre os quais se fofoca em Corumbá: sobre a vida conjugal, sobretudo as questôes de adultério e traição, e sobre a renda e o consumo das pessoas, desde os salários aos ganhos na fronteira do legal e do ilegal, principalmente no que diz respeito ao tráfico de drogas, prostituição ou contrabando. Como disse uma entrevistada, "aqui o povo fofoca muito sobre relacionamento e dinheiro". Outro entrevistado disse que as pessoas falam sobre "casamento, vizinhança e trabalho".

"As fofocas giram em torno da posição social da pessoa, profissão, se está ganhando bem... aqui é observado principalmente o olhar feminino nesses comentários, a escolha em ficar com o homem que tem melhor ganho financeiro, isso não quer dizer necessariamente melhor posição social. A de se observar os militares que além de serem alvos prediletos das "marias batalhões", são vítimas de fofocas em relação a sua vida intima, ou são tidos como viados ou cornos mansos ou grandes amantes." (I. Homem, 38 anos, morador, nascido em Corumbá).

"Quem fica com quem, a sexualidade das pessoas, o cara mais gostoso, independendo de ser casado ou não e os forasteiros e o que fazem na cidade, com as "apostas" de: "será que vai ficar muito tempo ou se vai embora porque não aguentou muito"." (T. mulher, 40 anos, mora há 4 anos em Corumbá).

Os relacionamentos amorosos são uma constante nas fofocas. Algumas falas de moradores indicam o peso e relevância desses assuntos e sua relação com os índices de violência na cidade, em torno da honra e reputação. Um entrevistado chegou a dizer "aqui em Corumbá, todo mundo é corno!".

\section{Outros entrevistados disseram:}

"A mulher só de ser gata, já é puta, biscate etc...Isso gera morte, gente! Já vi amigo meu morrer por causa de fofoca. O cara deu dois tiros nele...disseram que ele tava pegando a mulher dele. Mas ele nem tava porra nenhuma. Aqui tem muita violência por causa de fofoca e bebida, cachaça." ( $A$. mulher, 28 anos, moradora, nascida em Corumbá).

"Houve morte no carnaval na qual um rapaz se relacionava com uma mulher casada, caso nunca descoberto até os meses antes dos acontecimentos, fofocas chegaram ao ouvido do marido traído, o que foi o estopim para ele cometer o assassinato do amante de sua esposa." (F. homem, 32 anos, morador, nascido em Corumbá). 
"Em meu caso fofocaram que eu estava comendo a mulher de um grande amigo meu, pois me confundiram com o amante (de fato), mas isso serviu para abalar minha amizade com meu amigo até de fato ser descoberta a traição. Demorou um tempo até que ele viesse pedir desculpas. A fofoca de outro amigo, aconteceu pelo fato de ele querer ficar com uma menina, e esta menina tinha uma amiga que "todos diziam que era sapatão". Outra fofoca aí! O grande comentário que fizeram sobre ele foi que ele estava fazendo macumba para ficar com a menina, que sabendo deste comentário se afastou dele. Muito tempo depois ficamos sabendo que a menina que todos diziam que era sapatão foi quem saiu com essa fofoca." (I. Homem, 38 anos, morador, nascido em Corumbá).

"Conheço três meninas que tiveram fotos nuas compartilhadas por toda a cidade. Fizeram dois telefonemas em anonimato para minha casa às 3 h da manha para avisarem aos meus pais que estava em uma boate, outra vez avisando que eu estava entrando em um motel (o que no caso não era verdade, estava dentro de casa). Quando estava no ensino médio os próprios funcionários da escola disseram que estava tendo relações sexuais com o meu ex-namorado dentro da escola e que iriam avisar meus pais, o que era mentira, estava estudando com ele na biblioteca e o caso logo foi encerrado quando a escola foi ameaçada de processo por parte dos meus pais. Esses casos citados são alguns acontecimentos que ficaram marcados, mas o assédio é constante, diariamente, desde as perguntas simples, mas frequentes, como: 'onde você vai?' 'Vai fazer o que?' 'quanto você ganha'... até casos que geram pensamentos suicidas ou pessoas que mudam de cidade por conta disto. Por ser uma cidade pequena, todos tomam um rápido conhecimento de tudo, inclusive a família, indiscutiveis os danos gerados por tal "sufocamento social. " (L. Mulher, 24 anos, morou por sete anos em Corumbá).

Em uma entrevista com um policial civil da cidade, perguntei qual eram as principais ocorrências de violência que ele tinha que resolver. A cidade de Corumbá, que está na fronteira, tem uma série de crimes peculiares à região, principalmente do tráfico de drogas, que geram inúmeras ocorrências. Há também índices de violência em torno de assaltos, porém, o policial respondeu sem titubear: "violência doméstica". Esses crimes da esfera doméstica ocorrem muito em função das fofocas e da desonra pública causada pela sua propagação. ${ }^{6}$ Em geral, homens são vítimas de vinganças passionais e "crimes de honra" (em razão de ser alvo de fofocas como "cornos") e as mulheres são vítimas de violência, em casa, de seus maridos e

6 Para se ter uma ideia da dimensão dos crimes passionais da cidade basta acompanhar a seção de "Polícia" do principal jornal da cidade. Diário Corumbaense: http://www.diarionline.com.br. São recorrentes as reportagens de agressões, assassinatos e injúrias entre namorados, casais e vizinhos. Obviamente as fofocas e reputações atingidas estão diretamente envolvidas nessas ocorrências. 
companheiros. Essa situação foi relatada em algumas entrevistas. Quando perguntei os motivos da fofoca e quais os maiores alvos, uma moradora afirmou: "por ser cidade com poucos habitantes. E com uma cultura muito machista. Acima do normal'. Seguem algumas visóes apresentadas por moradores da cidade.

"Acho que tanto homens quanto mulheres fofocam e isso fere tanto um quanto outro. Mas por vivermos em.uma sociedade machista, quando a fofoca é sobre a quantidade de pessoas com quem uma mulher se envolve, ela prejudica mais as mulheres que os homens. Além disso, existe uma coerção social que faz com que as mulheres sempre se vejam como inimigas. E acho que a fofoca ganha mais força e maldade entre as mulheres que querem atingir umas às outras." (J. Mulher, 23 anos, nascida em Corumbá, mora em Campo Grande).

"Homens e mulheres fofocam uns sobre os outros o tempo inteiro, relatando casos extraconjugais, trabalho, desavenças da sociedade, entre outros. As maiores vítimas da fofoca acredito que sejam as mulheres, pelo molde da sociedade patriarcal que prevalece. Ex.: Homem trai: Garanhão/Macho Alfa; Mulher trai: promiscua, vagabunda/Vadia." (F. homem, 32 anos, morador, nascido em Corumbá).

"As maiores vítimas das fofocas são as mulheres. Isso não é pelo fato de os homens falarem. São as próprias mulheres que controlam a si próprias. E neste ponto há de se observar os sites como Vitrine virtual, que contribuem para este fato." (I. homem, 38 anos, morador, nascido em Corumbá).

"Quem sofre mais com os efeitos de uma fofoca, sem duvida são as mulheres. Estas tem a vida sexual controlada por todas as instituições em que se relaciona inclusive a familia. São apontadas por seu passado a todo o tempo, lamentável." (L. Mulher, 24 anos, morou por sete anos em Corumbá).

Outro motivo de preocupação local, referida a relacionamentos é a diferença de "padrão de vida", entre os namorados. Em geral se uma mulher ficar com um homem com salário maior, ela ficará "falada", sendo considerada como "aproveitadora". Uma entrevistada disse por que náo ficava em público com seu namorado, ressaltando a questão da inveja como motivadora das fofocas. Essa inveja, conforme já vimos, se dá entre “iguais”, entre pessoas próximas, e tem um sentido na entrevista de "segurar" ou mesmo "impedir" a ascensão social de uma mulher do mesmo estrato social da(s) ou do(s) fofoqueira(s) o(s): 
"Eu tenho certeza que se assumirmos algo agora vão fazer um inferno em nossas vidas. Até porque ele tem um padrão de vida bem mais alto que o meu. Tenho certeza que vão falar mal de mim. A inveja tem tudo a ver com fofoca." ( $A$. mulher, 28 anos, moradora, nascida em Corumbá).

A “mulher sozinha”, seja casada ou solteira, também é um dos objetos preferenciais de fofoca em Corumbá. Uma conhecida me contou que estava tomando sorvete com um homem jovem durante a tarde na cidade. Ao serem avistados, ligaram para seu marido, no trabalho, para avisar da suposta traição. O homem com quem tomava sorvete era seu irmão, que morava em outra cidade e a estava visitando. Essa história demonstra que o espaço público de circulação da mulher é ainda mais fechado e contido e sujeito a avaliaçóes e julgamentos, sempre com a ameaça de ser considerada uma "biscate". São inúmeros os casos de vídeos e fotos íntimas de mulheres da cidade que "vazam" na rede e destroem as reputaçôes, causando grande vergonha nas mulheres envolvidas. Elas passam a carregar esse estigma num constante processo de construçáo de si, a partir das fofocas, em novas performances além da oralidade, na propagação online desses vídeos íntimos que viralizam pela cidade. Essas categorias classificatórias da cidade como "biscate", "traficante", "puta”, "aproveitadora”, "pegador”, "corno" são todas tipos de estereótipos a partir dos quais as pessoas simplificam e reduzem seu universo social ao alocar os outros em um número reduzido de papéis sociais e de status possíveis (BAILEY, 1971). Para esse autor, esse fenômeno redutor das categorias sociais é uma parte importante do significado da reputação, que de fato é um fenômeno multifacetado, dependente também de outros fatores como as interaçôes sociais, dos campos de força em que uma pessoa circula, de seu comportamento e de como esse comportamento é avaliado sob diversos pontos de vista.

Outro assunto de grande interesse nas fofocas de Corumbá são as pessoas que podem estar envolvidas em atividades ilícitas, principalmente o tráfico de drogas. A proximidade entre as pessoas, seus nomes, rostos e os cargos que ocupam geram formas de sociabilidade e práticas muito específicas, em que as relaçóes de trocas de caráter pessoal predominam sobre as relaçóes de cunho impessoal e anônimas, propiciando também práticas de gestão das ilegalidades de modo localmente peculiar. Desde minha chegada à cidade escutava histórias sobre as pessoas que estariam ou estiveram 
envolvidas com o tráfico de drogas. "Fulano, dono da mercearia... mexia com droga... agora parou... mas tomou até tiro?". "Isso não é farmácia... é fachada...", "Esse é dono de tudo na cidade... hotel, puteiro, barco e é traficante... dos grandes?'. Além dos boatos, de fato a fronteira, como lugar propício aos negócios, sejam eles legais ou ilegais representa a possibilidade de promoção social para numerosos atores sociais, que utilizam o comércio de drogas para se capitalizarem e investirem em negócios legais. Como é quase impossível manter essas atividades no anonimato, muito em breve "todos" ficam sabendo.

"No plano mais local das profissões liberais, quem trabalha com "o que" ganha " $X$ "... como pode ter esse patrimônio ganhando pouco. Para quem tem de fato "culpa no cartório"... mas também entra a questão da inveja, por isso a fofoca é sempre destrutiva, pois em uma cidade pequena onde quase não há perspectiva de crescimento, mesmo que uma pessoa comece a crescer pelas vias legais sempre vão falar que "ela está mexendo com droga" $e$ por isso está ganhando dinheiro." (I. Homem, 38 anos, morador, nascido em Corumbá).

A chegada de policiais "de fora" significa um processo de recebimento social desses agentes em circuitos sociais de fofoca e nos grandes temas de "escândalo" ou "boatos" na opiniáo pública geral corumbaense. Assim, rapidamente, os agentes são socializados nas fofocas a respeito de quem são os traficantes, quem está envolvido em atividades ilícitas, quem se dedica ao pequeno tráfico na cidade e quem são os "poderosos" que trabalham com a venda de drogas no atacado para outras partes do Brasil. Seguindo as pistas de Gluckman (1963), podemos observar que o pertencimento ao "grupo" ou à cidade, como é o caso aqui apresentado, está diretamente relacionado com o conhecimento e compartilhamento das fofocas locais, que significa na gíria local, "saber das fitas que estão rolando". Assim, embora haja investigaçóes importantes que são feitas e operaçóes de repressão ao tráfico de drogas na fronteira, há um discurso na cidade de que "todos sabem quem faz o quê e tudo continua como está".

Um exemplo de como as investigaçóes policiais e as fofocas sociais da cidade se misturam e sobrepóem está num caso (modificado em alguns pontos a fim de não identificar as pessoas) que apresento a seguir: B. e M. são jovens mulheres. B. trabalha com M. em um órgão público. B. namora um policial civil. Não tem filhos e ele tem três filhos do casamento 
anterior. B. vive em uma pequena casa comprada por seu namorado e tem algumas dificuldades financeiras para se manter. M. é casada com um mecânico. Tem dois filhos com ele. Dizem as "más línguas" que seu marido, que trabalha na Bolívia, é na verdade traficante de drogas. M. usa roupas caras, vive no saláo de beleza e ganhou um carro zero quilômetro de seu marido, que tem uma motocicleta modelo esportivo. As pessoas desconfiam, falam muito. $\mathrm{O}$ policial civil manda um recado por B. para M.: "avisa pro marido dela que a gente sabe o que ele faz. Se ele continuar ostentando e gastando, a gente não vai poder continuar fingindo que nada está acontecendo, vamos prender ele”. B. conta o caso para as amigas, a fofoca circula. M. é objeto de inveja também, por seus bens de consumo, seu padrão de vida. Ganha fama de "aproveitadora”. A situação social do policial fica difícil porque as fofocas sobre o mecânico chegam aos seus ouvidos e dos colegas policiais, o que afeta, então, sua reputação pessoal e o prestígio da polícia. Assim, os policiais se sentem coagidos a investigar e prender o suposto traficante, muito mais por conta dessa pressão social em torno da fofoca, do que pelos atos ilícitos em si (que, caso fossem comprovados, levaria a uma prisão fácil de ser efetuada). $\mathrm{O}$ mecânico também se torna objeto de inveja e cobiça, distinguindo-se socialmente por seu novo padrão de consumo, assim como sua mulher.

Esse caso dialoga com o trabalho de Oliveira (2013), que apresenta a figura do "flagrantão", em sua pesquisa. Esse autor estuda a regulação da criminalidade na fronteira, a partir da organização dos pontos de venda de drogas, classificadas como "bocas familiares", inseridas nas relaçóes pessoais mais amplas da cidade. Entretanto, algumas "bocas" se tornam "famosas", caem na boca do povo e, de fofoca em fofoca, acabam saindo do padrão de discrição, rompendo com as normas tácitas, se tornando inaceitáveis do ponto de vista da polícia. A fama dessas bocas e dos seus boqueiros (vendedores de drogas) acaba se tornando seu ocaso.

Oliveira (2013) demonstra como alguns comerciantes de drogas ilícitas na fronteira denunciam outsiders para a própria polícia, em uma rede de informaçóes e fofocas que geram a prisão dos forasteiros que se aventuram a levar cocaína nos ônibus ou de carro pela BR 262, rumo a Campo Grande, como "bois de piranha". Nesse sentido, esse autor demonstra como em Corumbá as relaçóes sociais de proximidade garantem o funcionamento 
tanto das "bocas familiares" na cidade, no pequeno comércio de drogas, quanto dos grandes "traficantes" que enviam maiores quantidades de pasta base ou cocaína para fora da cidade. Assim, em Corumbá, é comum ouvir das pessoas que "todo mundo sabe quem são os traficantes da cidade", "como esse cara pode ter um carro desses trabalhando no comércio?", "farmácia tá dando dinheiro hein!", "mecânico nada, ele é traficante!", "a mulher dele só compra roupa em loja cara!”. Esses bens de consumo são, para a população em geral, a prova visual e material do que as fofocas diziam, produzindo uma série de julgamentos e acusaçóes que se difundem pela cidade. Mesmo assim, como não são tão secretas assim, essas atividades ilícitas justamente se estruturam e estabilizam ao longo do tempo também em função desse controle de informação. Há aqueles que estão acima de qualquer investigação, de qualquer operação policial, que desfrutam de grande prestígio social na cidade, negociando essa moralidade diariamente. As fofocas, boatos e a grande quantidade de informação pessoal à tona nessas cidades apontam para uma relativização da noção do "segredo", localmente, assim como para a participação de pessoas "conhecidas" (agentes estatais, empresários e políticos locais) nos esquemas ilegais. Essa relação entre o segredo e a fofoca, em Corumbá, se constrói em uma linha tênue entre a divulgação dessas informaçóes sob a forma de boatos (pois em geral a fofoca é anônima e difusa e o boato pode sempre ser considerado como uma "mentira") e seu silêncio (ninguém assume a divulgação dessas informaçóes, sob pena de sofrer sançóes). E sempre resta a dúvida inerente a qualquer fofoca: será mesmo? Será verdade?

\section{Considerações Finais}

Neste artigo, observamos a importância da fofoca na estrutura social da cidade de Corumbá, o que pode servir para comparação com outras localidades, situaçóes e contextos sociais. As entrevistas e as narrativas locais, assim como a observação participante nos permitiram conhecer sobre o que se fofoca na cidade, quais suas implicações e seus efeitos sociais. A partir dessas análises entendemos um pouco mais quais são os modelos ideais de comportamento e como essa moralidade é negociada no cotidiano em uma "arena" das reputaçôes. As relaçôes entre corumbaenses, ou de moradores de longa data com as pessoas "de fora", também foram discuti- 
das baseadas na dinâmica dos "estabelecidos e outsiders", apontando para disputas e competiçóes por espaço, trabalho e poder na cidade.

Assim podemos considerar a cidade de Corumbá como uma "arena” na qual circulam e competem os juízos morais e as disputas por prestígio e poder, no que Bailey (1971) chama de "política de reputação". Observamos empiricamente a eficácia e o poder da fofoca na coerção social, na formação de alianças e inimizades, na destruição de reputaçôes e da honra pessoal, assim como seu uso estratégico e pragmático nas disputas pessoais ou profissionais, que explicitam as competiçôes e conflitos de toda ordem. Quem é mais antigo na cidade detém mais informação, tem mais acesso aos centros de irradiação da fofoca, conhece melhor sobre um número maior de reputaçóes dos outros e possui, portanto, mais poder de mobilização e de se situar no jogo social, adquirindo maior capital simbólico sobre sua própria reputação e sobre as reputações alheias.

Por fim, procuramos relacionar os pequenos e íntimos eventos do cotidiano com processos mais amplos, sobretudo aqueles que se referem à política local, à violência doméstica, em crimes de honra, e ao tráfico de drogas na regiáo. A fofoca, como uma catalisadora de eventos, da chamada micropolítica, pode contribuir etnograficamente para investigaçóes sobre as relaçóes de trabalho, sobre o modo de se fazer negócios na fronteira, sobre a política local e a formação das hierarquias sociais, sobre os significados de relacionamentos amorosos, relaçóes de gênero, sobre a construção dos papéis sociais e do status e o posicionamento social dos indivíduos no "mapa" da cidade. A partir dos eventos mundanos e corriqueiros de Corumbá, que são objeto de "conversa fiada", podemos ter acesso à estrutura social da cidade, aos seus valores e entender quais disputas de poder e conflitos estão em questão. Estudar a fofoca nos põe, ainda, face a face com alguns dos elementos mais trágicos do jogo social.

\section{Referências}

ABRAHAMS, Roger, D. A performance-centered approach to gossip. Man, [S.1.], v. 5, n. 2, p. 290-301, 1970.

ALMEIDA, Luciana Schleder. Gaúchos, festas e negócios: o agronegócio da soja no Meio-Norte Matogrossense. 2013. 205 f. Tese (Doutorado em Sociologia e Antropologia) - Programa de 
Pós- Graduação em Sociologia e Antropologia. Instituto de Filosofia e Ciências Sociais da Universidade Federal do Rio de Janeiro, 2013.

ARENDT, Hannah. O Que é Política? Tradução de Reinaldo Guarany. 6. ed. Rio de Janeiro: Bertrand Brasil, 2006.

BAILEY, F. G. Gifts and Poison. The politics of reputation. Toronto: The Copp Clark Publishing company, 1971.

BESNIER, Niko. Gossip and the everyday production of politics. Honolulu: University of Hawaii Press, 2009.

BOURDIEU, Pierre. O poder simbólico. Rio de Janeiro: Bertrand Brasil, 1989.

COMERFORD, John. Onde está a Comunidade? conversas, expectativas morais e mobilidade em configuraçóes entre o rural e o urbano. RURIS-Revista do Centro de Estudos Rurais (UNICAMP), Campinas, v. 8, n. 2, p. 1-23, 2014.

COSTA. Gustavo V. L. O muro invisível: a nacionalidade como discurso reificado na fronteira Brasil Bolívia. Tempo Social, São Paulo, v. 25, p. 141-156, 2013.

ELIAS, Norbert.; SCOTSON, John. Os Estabelecidos e os outsiders. Sociologia das relações de poder a partir de uma pequena comunidade. Rio de Janeiro: Zahar, 2000.

EVANS-PRITCHARD, E. Os Nuer. Sáo Paulo: Perspectiva, 1978.

GLUCKMAN, Max. Gossip and Scandal. Current Anthropology, EUA, v. 4, n. 3, p. 307-316, 1963.

MALINOWSKI, Bronislaw. Argonautas do Pacífico Ocidental. Um relato do empreendimento e da aventura dos nativos nos arquipélagos da Nova Guiné Melanésia. São Paulo: Editora Abril, 1976.

OLIVEIRA, Giovanni França. Nas bocas da cidade de Corumbá (MS): O comércio de drogas na fronteira Brasil-Bolívia. 2013. 126 f. Dissertação (Mestrado em Estudos Fronteiriços) - Programa de Pós-Graduação em Estudos Fronteiriços da Universidade Federal de Mato Grosso do Sul, 2013.

PAINE, Robert. What is gossip about? An alternative hypothesis. Man, [S.1.], v. 2, n. 2, 278-285, 1967. New Series.

PERALDI, Michel. Economies criminelles et mondes d'affaire à Tanger. Cultures \& Conflits, Paris, n. 68, p. 111-125, 2007. 


\section{"Too much small talk in Corumbá": gossip, politics and morality in a Pantanal city}

\section{Abstract}

The city of Corumbá-MS, which has around 100,000 inhabitants. From the reading of Bailey (197I) we think the relations established between gossip and politics around personal reputations, and the belonging of people to one or more "moral communities" in the city, which we call the social circuits of gossip. Studying gossip can contribute ethnographically for researches on several elements of the social structure of the city: such as labor relations, on the way of doing business at the border, on local politics and the formation of social hierarchies, migrants flows, about the meanings of love relationships, gender relations, on the construction of social roles, status and social position of individuals in the "map" of the city.

Keywords: Gossip. Politics. Morality.

Recebido em: 22/09/2017

Aceito em: 06/05/2018 